\title{
PROBLEMS OF COORDINATION OF THE PURPOSES AND VITAL INTERESTS AT ENSURING SOCIAL AND ECONOMIC SECURITY
}

\author{
CShvaiba D., ORCID: 0000-0001-6783-9765; Ph.D., Belarusian Trade Union \\ of Workers of Chemical, Mining and Oil Industries; Belarusian National Technical University, \\ Minsk,Belarus,shvabia@tut.by
}

\section{ПРОБЛЕМЫ СОГЛАСОВАНИЯ ЦЕЛЕЙ И ЖИЗНЕННЫХ ИНТЕРЕСОВ ПРИ ОБЕСПЕЧЕНИИ СОЦИАЛЬНО-ЭКОНОМИЧЕСКОЙ БЕЗОПАСНОСТИ}

\author{
СШвайба Д. Н., ORCID: 0000-0001-6783-9765; канд. экон. наук, \\ Белорусский профсоюз работников химической, горной и нефтяной отраслей \\ промышленности; Белорусский национальный технический университет, \\ 2. Минск, Беларусь, shvabia@tut.by
}

Abstract. The development of an independent democratic country is inextricably linked to the transformation of all aspects of social life and, above all, of the economy. Financial and economic reforms in Belarus are focused on the creation of a socially oriented market system of management, which would ensure the most efficient use of resources at the lowest social costs. The experience of the last two decades shows that it is difficult to achieve this two-fold goal, but, undoubtedly, only in this case it is possible to guarantee the necessary level of well-being, low poverty and stability of the political system in the country. In the social economy, the definitions of 'equality' and 'poverty' are considered basic. On their basis is based public provision, the role of which in any state is to minimize poverty and maximize equality. However, both definitions are not considered identical. In a society with a significant level of inequality, it is possible to have a rather low level of poverty and Vice versa. Poverty is defined by the existence of criteria for individual members of society that do not meet accepted standards. According to the unanimous opinion of economists, poverty is an absolute evil and, as a result, it must be fought. There is no such consensus on equality. First of all, the definition of 'equality' is rather vague, which makes it possible to interpret it broadly and makes it difficult to clearly establish the degree of inequality in society.

Аннотация. Развитие независимой демократической страны неразрывно связано с преобразованиями всех сторон социальной жизни и в первую очередь - экономики. Финансово-экономические реформы в Беларуси ориентированы на создание социально направленной рыночной системы хозяйствования, при которой обеспечивалось бы максимально действенное использование ресурсов при наименьших общественных издержках. Опыт последних двух десятков лет демонстрирует, что добиться данной двуединой цели сложно, но, бесспорно, только в этом случае в стране возможно гарантировать необходимый уровень благосостояния, невысокий уровень бедности и стабильность политической системы. В социальной экономике определения «равенство» и «бедность» считаются базисными. На их базе основывается общественное обеспечивание, роль которого во всяком государстве сводится к тому, чтобы минимизировать бедность и максимизировать равенство. Впрочем, оба данных определения не считаются тождественными. В обществе со значительным уровнем неравенства имеет возможность быть довольно невысокий уровень бедности и наоборот. Бедность определяется наличием 
критериев для отдельных членов общества, не удовлетворяющих принятым эталонам. По единодушному воззрению экономистов, бедность - абсолютное зло и вследствие этого с ней нужно бороться. По отношению к равенству настолько единодушного мнения нету. В первую очередь определение «равенства» достаточно расплывчатое, что представляет возможным его широкое толкование и затрудняет четкое установление степени неравенства в обществе.

Keywords: socio-economic security, government, society, enterprise, employee, threat, security, interests, economics, analysis, system.

Ключевые слова: социально-экономическая безопасность, государство, общество, предприятие, работник, угроза, безопасность, интересы; экономика, анализ, система.

The development of an independent democratic country is inextricably linked to the transformation of all aspects of social life and, above all, of the economy. Financial and economic reforms in Belarus are aimed at creating a socially oriented market system of management, which would ensure the most efficient use of resources at the lowest social costs. The experience of the last two decades shows that it is difficult to achieve this dual goal, but, undoubtedly, only in this case in the country it is possible to guarantee the necessary level of well-being, low level of poverty and stability of the political system [1, p. 68].

In the social economy, the definitions of 'equality' and 'poverty' are considered basic. On their basis is based social security, the role of which in any state is to minimize poverty and maximize equality. However, both of these definitions are not considered identical. In a society with a significant level of inequality, it is possible to have a rather low level of poverty and Vice versa. Poverty is determined by the existence of criteria for individual members of society that do not meet accepted standards. According to the unanimous view of economists, poverty is an absolute evil and as a consequence we need to fight it [2, p. 29]. There is no such consensus on equality. First of all, the definition of 'equality' is rather vague, which makes it possible to interpret it broadly and makes it difficult to clearly establish the degree of inequality in society.

Barr in the study 'the Economy of the social state' [3, p. 97] defines equality as representing all members of society equal opportunities. In this regard, the concepts in relation to the choice of public policy aimed at maximizing equality differ. Socialists who interpret inequality in a narrower sense - as property inequality, believe that this is the same negative phenomenon as poverty, because it leads to social tension and prevents the development of opportunities for individuals related to the lower strata of the population. As a result, the government must make significant efforts and spend resources to reduce inequality. The result of this policy is a progressive scale of income taxation, significant inheritance taxes and a significant range of social programs [4-5] for the poor. At the same time, liberals, who understand equality in a broader sense, insist that the country's interference in the financial and economic activities of agents is considered a violation of the principle of equality, because. in this case, the government takes away the share of income from more effective members of society and thus suppresses the manifestation of entrepreneurial initiative. According to the opinion of liberals, a similar practice has the opportunity to lead to a slowdown in financial and economic development, in the end of which everyone will lose: both the wealthy and the poor. In consequence, the liberals are for more restrained public programs, aimed primarily at poverty reduction $[6$, p. $73 ; 7$, p. 36; 8, p. 299]. The world-famous Russian and American scientist - macro-sociologist, a prominent son of the Komi people Pitirim Alexandrovich Sorokin, who proposed the concept of 'integralism', the scientific basis of which is set out in his four-volume 'Social and cultural dynamics' — a kind of 'Bible' of integralism- 
discussed this ideological contradiction a lot in his research. Going to replace liberalism and socialism in historical perspective by denying them integralism takes the legacy of all the value that produced these main currents of the industrial age and, integrating this valuable melts into a new synthesis, free from one-sidedness, extremism and does not meet new conditions of society's development regulations. This is a breakthrough in scientific knowledge, but a breakthrough based not on the destruction and denial of everything first achieved, but on a jump in the cumulative accumulation of the amount of knowledge and bringing it into line with a radical changing society, with the transition to a humanitarian-noosphere post-industrial civilization and an integral sociocultural system which is less characterized by inequality.

Here it is necessary to explain how inequality is measured. Due to the fact that the use of the definition of inequality in this case is not suitable, it is necessary to use a narrower interpretation for the measurement, but just property inequality. As an indicator of inequality, the dispersion of joint income between individuals in the economy is used. The Lorentz curve shown in figure 1 gives a clear idea of inequality in the economy. The abscissa axis represents part of the population and the ordinate axis represents part of the income in the economy. The Lorentz curve shows how much of the income falls on the corresponding share of the population. For example, in the figure you can see that $40 \%$ of the population receive less than $20 \%$ of the total income. The position of perfect equality will correspond to the Lorentz curve coinciding with the diagonal. The greater the level of inequality, the greater the deviation of the curve from the diagonal. To quantify the inequality, the Gini coefficient is applied-the ratio of the area of the OEDCBAO area to the joint area of the triangle OEF. With full equality, the Gini coefficient is zero.

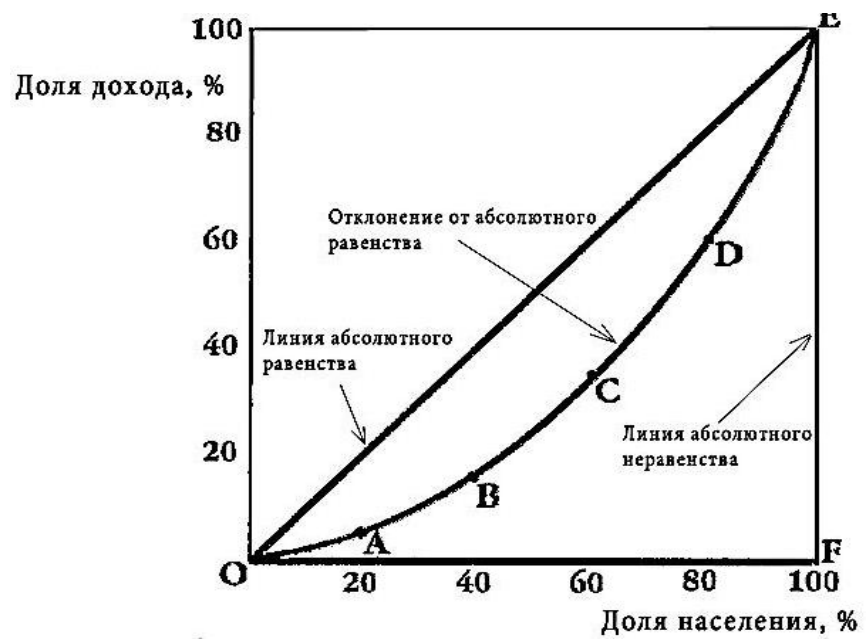

Figure. Lorenz curve.

In today's world, poverty is undoubtedly associated with a low level of financial and economic growth, and its elimination is considered the first step towards financial and economic recovery. As for inequality, there is no obvious link with financial and economic development. There are all sorts of theories explaining the impact of inequality on financial and economic recovery. However, they are not satisfactory, because they can predict the opposite results. However, the least empirical evidence shows a link between inequality and financial and economic development. For the first time this fact was noticed by the economist S. Kuznets in 1955, He demonstrated that financial and economic development initially leads to increasing inequality, and later to reduce it. This dependence was called The Kuznets curve, or the inverse U-curve. After that, a large number of researchers agreed with this dependence for both developed and developing countries. 
The justification of the Kuznets curve in theory is as follows. We consider a two-sector economy in which the 1st economic sector (for example, agriculture) is considered to be more technologically backward than the 2 nd (industrial production). Initially, the 1 st sector is considered to be predominant in the economy. Since the public is mostly engaged in this sector, all income is approximately equal and conditional equality is formed in the country. At the same time, part of the 2nd sector is growing smoothly in the economy, and due to higher labor productivity, a large salary is formed in it, which contributes to the flow of labor to it. In this case, it is expected that wages in the 2 nd sector has the opportunity to be not so uniform as in the 1st. This is explained by the initial influx of unskilled labor into the sector. This situation contributes to increasing inequality both in the economy as a whole and in the 2 nd sector as it develops.

The process lasts as long as the 1st sector is not enough labor, which leads to an increase in wages. At the same time, financial and economic progress associated with success in the 2nd sector, has the ability to contribute to the increase in productivity in the 1st sector of the economy, which also contributes to the increase in wages. Over time, workers who have moved from sector 1 to sector 2, receive the necessary professional skills, their skills are growing, which contributes to the growth of their income. As a result, inequality in the economy decreases and welfare increases. This process guarantees the rise of social and economic security.

Thus, the main function of ensuring socio-economic security is that the situation and trends of progress that ensure socio-economic security exclude or minimize harm not only the potential of individual economic entities, but also the potential of the economy as a whole.

In a number of scientific papers securities is universally postulated as a position of protection of the main interests of the individual, society, economic entity and the country from internal and external hazards. The main interests include array of needs, the implementation of which ensures the ability to the modern development of the individual, society, the economic entity and of the country - the basic objects of security [9, p. 9; 10, p. 508].

For any socio-economic system, the presence of a hierarchical structure of the organization of the system or its subsystems is considered a mandatory property. The economy is a polyhierarchical system. When considering the hierarchical structure of management of the production process, it is important to take into account one property of the financial and economic systeminformation incompleteness. Here, as a rule, it is customary to refer to the theorems of K. Gödel (1931). There is a qualitative description of the incompleteness of the information array.

The 1st Theorem of Gödel. For any system a not all current positions are provable within the limits of a 2-nd Gödel's theorem. The consistency of the formal system A cannot be justified by the methods of this system.

For the financial and economic system, Gödel's theorems are interpreted in this way [11, p. 639]: within the financial and economic system of an economic entity, it is impossible to prove its objective function, if we do not take into account the requests of a higher value-the country's economy. Otherwise, the national economic costs are inevitable. In other words, subsystems are not able to work effectively if the interests of the including system are not provided. Moreover, without the subordination of financial and economic interests subsystem has the ability to cause significant damage to the entire system. Failure to comply with the conditions of subordination, subordination of socio-economic interests can lead to the destruction not only of the inclusive system, but also included, because it is impossible to prove the consistency of the included systems, if you do not refer to a higher level system. The speed of movement of the system is largely dependent on the synchronization of socio-economic interests of its subsystems and the interests of the management system at a higher level. 
In the publication of A. V. Kolupayev [12], with reference to the work of the Russian economist, The concept of 'security' is taken from the theory of global relations and refers only to the systems in which the subjects of political decision-making work. While the majority of researchers currently use the concept of 'security' as the subject of macroeconomics and microeconomics subjects [13, p. 7].

In this regard, socio-economic security should be considered as an interconnected system of its various meanings: global, state, at the level of society, individual enterprise and individual.

Under the global socio-economic security is understood such a situation of the international economy, which supports mutually beneficial cooperation of States in the resolution of state and international economic problems, free choice and implementation of their own strategy of socioeconomic formation and role in the global division of labor. It can be assumed that global socioeconomic security is guaranteed with the support of the system of global financial and economic organizations formed by the international community: IMF, IBRD, WTO, FAO, etc. Partnership agreements on the free movement of capital, products and services, consideration of mutual socioeconomic interests, the rejection of force pressure, equal relations with the least developed countries in financial and economic terms can play a significant role in ensuring global socio-economic security.

The socio-economic security of the state is characterized by a system of values that combines the capacity of the economy to work in the mode of expanded reproduction, the stability of the financial and economic system, the effective structure of international trade, maintaining the required level of scientific potential, the preservation of a single financial and economic space, the creation of financial, economic and legal conditions that exclude the criminalization of society, ensuring state regulation of socio-economic processes, ensuring a rational standard of living of the population.

Assessment and management of social and economic risks, as well as the state of the economy are considered to be the relevant criteria and components in ensuring the working functioning of the economic entity.

Unfortunately, now there is a financial and economic mechanism of management, in which, for example, the increase in the productivity of the industrial sector is not considered a promise for the realization of economic interests. There is a deficit in the relationship between the national economic interests and the interests of the economic entity. Why is this happening? To date, the financial and economic management system does not have a clear division of functions of management bodies; which would reflect the specifics of the structure of socio-economic interests. There is no organizational system: an integrated system (a system with strong relationships between the selected elements), which would identify the economic and national socio-economic interests and would bear financial and economic responsibility for it (it should be noted that the issue of socio-economic responsibility is now extremely acute). And this despite the fact that back in 1965 . Kuznets wrote a paper [14], in which he proved that investments in human development are more relevant and that it is more significant capital among other factors of the production process. In the case if you apply first job the 1st of the developers of the human capital theory of Theodore Schultz $[15$, p. 12] (the work of Gary Becker came out a little later), it is possible to see that Smith was thinking in the same direction and understood as determining the future once this factor of the production process. But until now, in the domestic scientific literature on the investment process and innovative approaches prevails technocratic view, and human capital is often not mentioned.

Macroeconomic interests are presented in the form of abstracted proposals of higher authorities to lower ones. The separate state bodies of management do not represent the complete system of management which entered into social and economic relations with the independent 
enterprises with various forms of ownership. In this situation, economic entities are usually engaged in the implementation of their own current interests, which take precedence over the state interests.

Under the socio-economic security of the individual is understood such a situation of human life, which supports the legal non-economic protection of its actual interests, compliance with constitutional rights and obligations. The main hazards of the individual are the rights of the consumer, nonpayment of pensions and wages, unemployment, irreparable impairment of savings, etc. Socio-economic security of the individual is largely determined by the state of the economy. Man is considered the main component of the financial and economic system. Its focus on raising labor productivity, on lowering socially necessary expenses per unit of useful effect has a decisive meaning in the development of the economic management system.

In order to ensure the socio-economic security of the country, to prevent the threats and dangers taking place, or to eliminate the results of their influence, it is necessary that the financial and economic system of the country is able to meet the array of socio-economic demands of society. At the heart of socio-economic demands are the living conditions of people and their productive activities. Satisfaction of social and economic needs should form the necessary conditions for the life of society, its spiritual life, to reproduce both social and personal aspects of the production process.

Socio-economic queries - that's kind of the demand of the society in financial and economic. The boundaries and design of these queries are not uniform.

The socio-economic demands may include the needs for material goods (food, housing, clothing, etc.); services; energy, heat, to ensure the spatial movement of things and people; scientific developments; criteria that promote the reproduction of the labor force; products of labor, which are the material base of productive and public infrastructure.

Another necessary feature of the socio-economic system, due to the adaptability of its behavior, is purposefulness.

The goal is the object of aspiration, in advance of the intended final purpose, the expected result of the activities of the system, in the name of what?

In General, under the Objective of the system is understood to be the boundary behavior of the system that somehow organizes an array of system States so that one state more responsible than the other [16, p. 700]. The formal expression of the goal is the objective function of the system. There are definitions of the purpose and means of realization of the purpose. The goal has the ability to be both an Autonomous category and a function of the means of its implementation.

At the same time, the behavior of any system has the ability to be described both in the definitions of the purpose and target functionals (axiological description), and in the definitions of the direct impact of 1-their variables on others, without the use of definitions of the purpose and means (causal description). In the first description, the system is attributed to the property tends to achieve a personal goal. In the second description, the presence of some purpose in the system is not expected, and all its future States are determined by the past States and the action of the external environment. Often the system may have several goals or several functions, but all of them will be mutually balanced. Goals have all the chances to form a hierarchy: in the functioning of the system, the most significant goals are achieved first, followed by the least significant.

Purposefulness takes place at different levels of the organization of the socio-economic system. In the hierarchy, the goals of the lower values are directly related to the interaction of the system and the outdoor environment at the moment, and the goals of the higher values determine the behavior in the future. The way of studying the mechanisms of purposeful behavior of the system is carried out by means of modeling. 
Under the purpose of modeling we understand the goals that the scientist puts forward in the construction of the model. These include the description and study of the studied processes, forecasting, obtaining fresh information about the object, evaluation of management strategies, comment on the phenomenon, the study of the state of the object and other things that have the ability to interest the scientist.

If a scientist is considered an observer and evaluates the system from the outside, depending on the convenience, he has the opportunity to approach the analysis of the system either axiologically or causally. If a scientist is considered to be a part of the system and has the ability to influence its position, the task of the system will depend on the goals of the scientist. In this case, the behavior of the whole system is not possible to be described by the researcher in causal terminology and implies freedom of choice or acceptance of conclusions by the researcher.

\section{References:}

1. Yaroshevich, V. (2015). Sotsial'nye gruppy belorusskogo obshchestva v usloviyakh transformatsii. Belarusskaya dumka, (10), 68-73.

2. Lipatova, L. N., Gradusova, V. N., \& Modin, E. V. (2015). Kharakteristika zhiznennogo urovnya naseleniya $\mathrm{v}$ kontekste voprosov ekonomicheskoi bezopasnosti. Ekonomika i upravlenie: vchera, segodnya, zavtra, (5), 26-37.

3. Barysheva, G. A., \& Yakimova, T. B. (2013). Natsional'naya ekonomika. Tomsk, 204.

4. Shvaiba, D. (2019). Dynamic regression models of forecasting indicators of social and economic security. Bulletin of Science and Practice, 5(1), 249-257.

5. Shvaiba, D. (2018). The content of the forecast of socio-economic security of the industrial sector of the republic of Belarus. Bulletin of Science and Practice, 4(8), 177-182.

6. Isanbaeva, S. D. (2015). Ekonomicheskie aspekty sotsial'noi spravedlivosti. Kazanskaya nauka, (1), 72-74.

7. Kolesnikov, V. V., Makarov, I. N., \& Yudin, O. I. (2016). Ekonomicheskaya svoboda i spravedlivost' kak bazisnye faktory prostranstvennogo i regional'nogo razvitiya strany. Finansy. Ekonomika. Strategiya, (2), 34-38.

8. Popov, A. N., \& Murzagalina, G. M. (2016). Ideya spravedlivosti v ekonomicheskikh otnosheniyakh lyudei: istoriya i sovremennost'. Nauchnoe obozrenie, (19), 296-304.

9. Senchagov, V. K. (2013). Novye ugrozy ekonomicheskoi bezopasnosti i zashchita natsional'nykh interesov Rossii. Problemy teorii i praktiki upravleniya, (10), 8-18.

10. Kovalenya, A. A. (2013). Respublika Belarus' - Evropeiskii soyuz: problemy i perspektivy partnerstva. Minsk, Belarus. navuka, 525.

11. Lvov, D. S. (2005). Vvedenie v institutsional'nuyu ekonomiku. Moscow, Ekonomika, 639.

12. Kolupaev, V. A. (2002). Formirovanie kontseptsii natsional'noi ekonomicheskoi bezopasnosti $\mathrm{v}$ zarubezhnykh stranakh. Beloruskaya ekonomika: analiz, prognoz, regulirovanie, (12), 2-9.

13. Lapchenko, E. N., \& Bykov, A. A. (2012). Ekonomicheskaya bezopasnost' predpriyatiya i riski. Minsk, Amalfeya, Misanta, 184.

14. Kuznets, S. (1965). Economic growth and structure. New York, Heinemann, v. 8, 378.

15. Schultz, T. W. (1961). Investment in human capital. Amer. Econ. Rev., 51(1), P. 1-17.

16. Gontareva, I. I., Nemchinova, M. B., \& Popova, A. A. (1975). Matematika i kibernetika v ekonomike. Moscow, Ekonomika, 700. 


\section{Список литературь:}

1. Ярошевич В. Социальные группы белорусского общества в условиях трансформации // Беларусская думка. 2015. №10. С. 68-73.

2. Липатова Л. Н., Градусова В. Н., Модин Е. В. Характеристика жизненного уровня населения в контексте вопросов экономической безопасности // Экономика и управление: вчера, сегодня, завтра. 2015. № 5. С. 26-37.

3. Барышева Г. А., Якимова Т. Б. Национальная экономика. Томск: Изд-во Том. политехн. ун-та, 2013. 204 с.

4. Shvaiba D. Dynamic regression models of forecasting indicators of social and economic security // Бюллетень науки и практики. 2019. Т. 5. №1. С. 249-257.

5. Shvaiba D. The content of the forecast of socio-economic security of the industrial sector of the republic of Belarus // Бюллетень науки и практики. 2018. Т. 4. №8. С. 177-182.

6. Исанбаева С. Д. Экономические аспекты социальной справедливости // Казанская наука. 2015. №1. С. 72-74.

7. Колесников В. В., Макаров И. Н., Юдин О. И. Экономическая свобода и справедливость как базисные факторы пространственного и регионального развития страны // Финансы. Экономика. Стратегия. 2016. №2. С. 34-38.

8. Попов А. Н., Мурзагалина Г. М. Идея справедливости в экономических отношениях людей: история и современность // Научное обозрение. 2016. №19. С. 296-304.

9. Сенчагов В. К. Новые угрозы экономической безопасности и защита национальных интересов России // Проблемы теории и практики управления. 2013. №10. С. 8-18.

10. Коваленя А. А. Республика Беларусь - Европейский союз: проблемы и перспективы партнерства. Минск: Беларус. навука, 2013. 525 с.

11. Львов Д. С. Введение в институциональную экономику. М.: Экономика, 2005. 639 с.

12. Колупаев B. А. Формирование концепции национальной экономической безопасности в зарубежных странах // Белоруская экономика: анализ, прогноз, регулирование. 2002. №12. С. 2-9.

13. Лапченко Е. Н., Быков А. А. Экономическая безопасность предприятия и риски. Минск: Амалфея, Мисанта, 2012. 184 с.

14. Kuznets S. Economic growth and structure. New York: Heinemann, 1965. VIII. 378 p.

15. Schultz T. W. Investment in human capital // Amer. Econ. Rev. 1961. V. 51. №1. P. 1-17.

16. Гонтарева И. И., Немчинова М. Б., Попова А. А. Математика и кибернетика в экономике. М.: Экономика, 1975. 700 с.

Работа поступила

в редакичию 17.04.2019 2.
Принята к публикации 21.04.2019 2.

Ссылка для цитирования:

Shvaiba D. Problems of Coordination of the Purposes and Vital Interests at Ensuring Social and Economic Security // Бюллетень науки и практики. 2019. Т. 5. №5. С. 301-308. https://doi.org/10.33619/2414-2948/42/39.

Cite as $(A P A)$ :

Shvaiba, D. (2019). Problems of Coordination of the Purposes and Vital Interests at Ensuring Social and Economic Security. Bulletin of Science and Practice, 5(5), 301-308. https://doi.org/10.33619/2414-2948/42/39. 